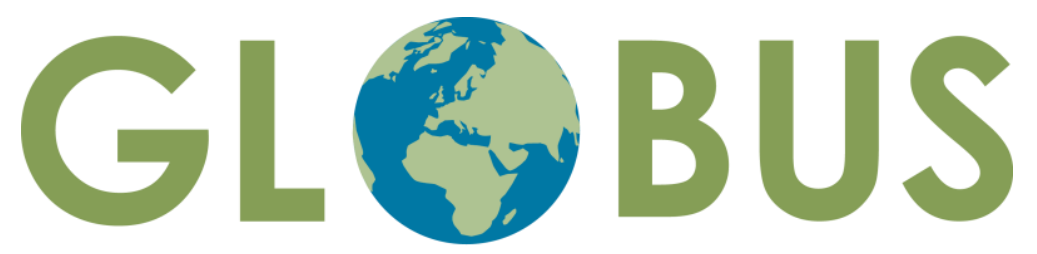

Reconsidering European Contributions to Global Justice

\title{
EU Aid for Trade Mitigating Global Trade Injustices?
}

Samuel Brazys, Arya Pillai and Johanne Døhlie Saltnes

GLOBUS Research Papers

4/2019 - October 2019 
Samuel Brazys, Arya Pillai and Johanne Døhlie Saltnes

\section{EU Aid for Trade: Mitigating Global Trade Injustices?}

GLOBUS Research Paper 4/2019

October 2019

(C) Samuel Brazys, Arya Pillai, Johanne Døhlie Saltnes

GLOBUS Research Papers (online) | ISSN: 2535-2504

http://www.globus.uio.no/publications/globus-research-papers/

Samuel Brazys is Associate Professor at the School of Politics and International Relations, University of Dublin

Arya Pillai is Postdoctoral Fellow at the School of Politics and International Relations, University College Dublin

Johanne Døhlie Saltnes is Postdoctoral Fellow at ARENA Centre for European Studies, University of Oslo

Reconsidering European Contributions to Global Justice (GLOBUS) is a research project that critically examines the EU's contribution to global justice.

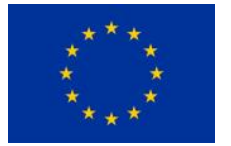

Funded by the European Union's Horizon 2020 programme. This work is the sole responsibility of the author. It does not reflect the opinion of the EU. The Research Executive Agency is not responsible for any use that may be made of the information it contains.

\footnotetext{
6 www.globus.uio.no

七 Twitter:@globus_h2020

f Facebook:@globus.h2020
}

Issued by:

ARENA Centre for European Studies

University of Oslo

P.O. Box 1143 Blindern

0318 Oslo, Norway

www.arena.uio.no

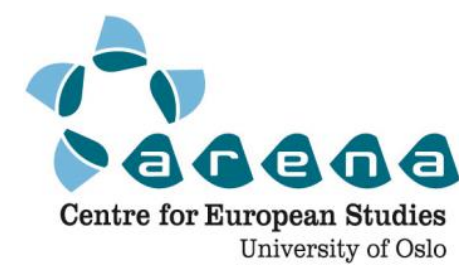




\section{Abstract}

Does European Union (EU) foreign economic policy contribute to global justice or does it further neo-colonial structures of economic dependence? To assess this question, we evaluate if and how the EU's 'Aid for Trade' (AfT) efforts have impacted the political, institutional and economic relationships with six sub-Saharan African countries. After discussing the conceptualisation of global justice as non-domination, we evaluate how the AfT initiative has changed the politics and institutions of trade negotiations between Europe and its partner countries. We then take advantage of sub-national datasets on AfT and foreign direct investment (FDI) to see if EU AfT is effective in attracting FDI, either from its own source countries and/or from non-EU sources. Our findings are suggestive that EU AfT initiatives have mitigated global trade injustices by levelling the political, if not institutional, playing fields and by working to attract FDI from both EU and non-EU sources.

\section{Keywords}

Aid for Trade, neo-colonialism, dependency, foreign direct investment, global justice

Research for this paper has received funding from the European Union's Horizon 2020 research and innovation programme under grant agreement no. 693609 (GLOBUS). 


\section{Introduction ${ }^{1}$}

The potential for trade to counteract the inequities between developing and developed countries is contested. Trade can serve as an instrument for growth and sustainable development, however, many argue that global trade contributes to increased inequality, if not exploitation, between rich and poor countries (Therien 1999). This argument has its roots in the 'dependecia' school of the 1960s and 1970s (Caporaso 1978; Walleri 1978), but has been reinvigorated in 'neo-dependency' and neo-colonial critiques (Hoogvelt 2006; Langan 2018). For instance, scholars have pointed to how the structural adjustment policies enacted by the Wold Bank and International Monetary Fund (IMF) during the Washington Consensus period have reduced the effect of growth on poverty reduction (Easterly 2001). Significant attention has also been paid to how the institutional framework that regulates global trade enables richer states to dominate developing countries (Stiglitz 2002). Inherent power asymmetries between states can further reinforce inequities by influencing the 'rules of the game' in favour of developed countries' interests (Langan and Scott 2014). Hence, both from a redistributive and political point of view, arguments have been made that the global trade regime can entrench economic patters that favour richer states, subjecting developing countries to domination.

Aid for Trade (AfT) has been presented as a panacea to the unfair consequences of global trade (OECD 2007, Hoekman 2002; Hoeckman and Prowse 2005). A broad moniker, AfT encompasses economic infrastructure which might facilitate trade or trade-related production, training on customs or other trade-related regulatory issues, or industry-specific trade development measures (Brazys and Lightfoot 2016). According to Lam (2008: 273) Aid for Trade is 'increasingly [...] seen as the missing link that will help to make trade a true engine of growth for poorer countries'. According to Luke and Bernal (2011: 352) AfT 'gives concrete expression to the objective of securing greater developing country participation in international trade', while Makhan (2012: 106) holds that 'the value-added of the AfT agenda lies in the processes it has triggered and opportunities for coordination have been related between [...] actors on the demand-side (recipients) and the supply-side (donors)'. Furthermore, donors, such as the European Union (EU), have embraced the AfT agenda and have given it a central place in its development cooperation framework (Council of the EU 2007a, 2017). From the point of view of the EU, by 'supporting demand-driven reforms of trade-related policies as well as removing supply-side constraints related to productive capacities, economic infrastructure and trade-related adjustment, AfT is crucial for developing countries in order to implement and benefit from trade agreements' (Council of the EU 2007b).

However, critics of the AfT agenda hold that AfT does not deliver what it promises. Several non-governmental organisations (NGOs) have pointed to the fact that there is little

\footnotetext{
${ }^{1}$ The authors thank participants of the workshop 'The EU's trade and development policies in a changing global environment' hosted by ARENA Centre for European Studies, University of Oslo for useful comments and suggestions. All errors remain the authors' own.
} 
information available as to whether AfT alleviates poverty. ${ }^{2}$ According to Langan and Scott (2014: 151) AfT is a strategic move by donors which serves as a 'means of legitimating entrenched power relations via the construction of common-sense acceptance of "propoor" liberalisation'. The motivation behind AfT is therefore assumed to be tied to domestic economic interest rather than development concerns (Langan 2016; See also Holden 2014; Brazys 2013). In addition, critics have pointed to the fact that AfT does little to remedy the 'inequities of the rules themselves' (Langan and Scott 2014: 153). Indeed, Langan (2018: 61) goes so far as to characterise AfT as a neo-colonial project that acts 'as a subsidy for foreign corporate involvement'. Hence, it remains unclear whether the Aid for Trade agenda has rectified the inequalities and unwanted consequences of global trade or changed the 'rules of the game' in any significant manner. The EU's AfT efforts therefore merit further investigation.

In this paper we ask if the EU's AfT initiative has helped usher in a new era of nondominating economic relations between the EU and Africa. To answer this question we make use of a justice perspective on domination as the essence of injustice and the possibility of non-domination between states (Eriksen 2016; Pettit 2010). Our investigation considers both whether the AfT has brought changes to the global trade regime in terms of decision-making, i.e. influencing the rules of the game, but also in terms of shifting empirically observable economic outcomes.

The paper proceeds by first briefly elaborating on the justice perspectives of domination and non-domination. We then consider if the AfT initiative has promoted global justice. We do this in two parts. First, we examine the extent to which the political and institutional processes of the AfT initiative have promoted non-domination between developing states in Africa and their wealthier counterparts in the settings of the World Trade Organization (WTO) and the Economic Partnership Agreement (EPA) regional negotiations. Second, we investigate if the observable outcomes of the EU's AfT initiatives support a neo-colonial narrative or instead serve to liberate partner countries from economic domination. In order to do this, drawing on Langan's (2018) critique of AfT as a handout to foreign commercial interests, we take advantage of localised, project-level information on both AfT and foreign direct investment (FDI) to employ a spatial-temporal approach to determine if local EU AfT attracts FDI to the same locality. We are able to examine our hypothesis of domination by taking advantage of information on FDI source countries. If EU AfT remains primarily a neo-colonial endeavour, we would expect to see that it only, or disproportionally, attracts FDI from EU member states. Alternatively, if EU AfT works against economic domination, then we would expect it to attract non-EU FDI as strongly, if not more strongly, than EU FDI.

\footnotetext{
${ }^{2}$ For instance, Stephen Twigg of the International Development Committee notes 'A strategy heavily weighted towards trade alone can actively disadvantage the most marginalized groups', see: https://www.reuters.com/article/us-britain-eu-aid/worlds-poorest-risk-losing-out-as-brexit-britainpushes-aid-for-trade-idUSKBN1K71S9.
} 


\section{A global justice perspective: Trade domination and the possibility of non-domination between states}

A common argument regarding globalisation is that while increased levels of trade between states has been a key driver of economic growth, its benefits have been skewed in favour of richer states (Krugman 1981; Stiglitz 2002). Global trade governance, mainly regulated by the WTO, the successor to the General Agreement on Tariffs and Trade (GATT), has enabled relations of dominance between states. According to Wilkinson (2017: 427) ' $[\mathrm{t}]$ rade negotiations remain the preserve of the most significant economic states, with those that are neither principal suppliers nor major importers playing little more than a bit part'.

To be dominated is to live at the mercy of others. It is to be subjected to arbitrary power and to be dependent on particular others (Eriksen 2016). Relations of dominance are fundamentally unjust, and justice requires putting an end to arbitrary forms of power. Unjust outcomes are often referred to in redistributive terms. However, dominance also lies in the unjust procedures and institutional rules of the game which can give more power to some states over others. In the international relations literature, the lack of trade justice between states is often linked to power. For instance, one prominent critique of the WTO is that the most important decisions are made by the most powerful states in the 'green room', away from the influence of less powerful states (Schott and Watal 2000).

In accordance with Pettit (2010) and Eriksen (2016) we define dominance as the essence of injustice. Political trade domination implies that wealthier states use their power to skew trade negotiations in their favour at the cost of developing countries interests and preferences. The observable economic consequence of this political trade domination is dependency, or neo-colonial ties wherein a developing country is disproportionally reliant on markets or capital from a particular economy, often facing disadvantageous terms of trade (Walleri 1978). Neo-colonial trade policies serve the commercial interests of donors and their agents, rather than increasing the trade capacity of developing countries.

International institutions governing global trade have long faced criticism for fostering domination of the developed global north over the developing global south (Shaw 1979; Onwuka 1989; Mahler 1994). In particular, they have been accused of prioritising trade liberalisation above concerns for human rights, the environment, and redistributive equality (Føllesdal 2016). Such critiques have also been made towards particular trading partners, including the European Union, especially from its African, Caribbean and Pacific (ACP) counterparts (see for instance Moulds 2015). In the following two sections we investigate to what extent and how European AfT has reduced domination both in the institutional settings of the global trade regime, but also in observable consequences of economic practice. 


\section{The Aid for Trade Initiative:}

\section{An endeavour to establish non-domination in the politics and institutions of the global trade regime?}

The multilateral global trade regime orbits around the WTO. The success of the WTO in enhancing trade justice is contested. According to Stiglitz (2002) the "the IMF, World Bank and WTO [...] set the rules of the game [...] in ways that, all too often, have served the interests of the more advanced industrialized countries - and particular interests within those countries - rather than those of the developing world' (quoted in Føllesdal 2016). However, some power-mediating structures exist in the WTO system which have given weaker states the possibility to challenge powerful countries.

The launch of the Doha Development Agenda negotiations marked the start of an emerging consensus for putting trade at the service of development and making multilateral trade governance work better for developing countries. Without significant market power, developing countries have used their veto power in the WTO to resist any initiative that does not deliver development. The consensus-based decision-making system in the WTO has served to mediate the power asymmetries that exist between developed and developing countries, at least to a certain extent (Murray-Evans 2019; Wilkinson 2017). The WTO system further allows for alliances between different groups of countries. These groups often speak with one voice in WTO negotiations, using one country as the coordinator and negotiation team. Examples of such groups are the African group, the Least Developed Countries group and the ACP group. Forming such coalitions has at times proven a successful strategy. In the Singapore Ministerial conference in 1996 the group of 77 resisted the EU and the US' demand for including standards for environmental protection and labour rights in the WTO (Vigrestad 2018).

As part of the Doha-round in the WTO, the Aid for Trade initiative was agreed upon as a way of making the institution more development friendly. It was formally launched in 2005 at the Hong Kong Ministerial of the WTO (WTO 2005). The initiative's aim was to help developing countries take better advantage of global trade inter alia by alleviating supply-side constraints and build trade-related infrastructure (Luke and Bernal 2011).

At first sight, the AfT initiative can be interpreted as a victory for developing states, in terms of reducing the institutional domination of their northern counterparts. The African group in the WTO referred to the initiative as home-grown:

The African ownership of this initiative is paramount. The genesis for this initiative derives from Africa and its political leadership at the highest level. This present mandate therefore should be brought to add value and should be funded with predictable resources.

(African Group in WTO 2006)

Donors also confirm that projects conducted under the AfT initiative have influenced the way they work with recipients. Gareth Thomas, former United Kingdom Minister for 
Development, described the pilot AfT project 'the North-South Corridor' in East and Southern Africa in the following way:

It was also a breakthrough for our ways of working as donors; grounded in a true African-led process, donors agreed to adopt a regional approach and offer regional solutions.

(Thomas 2009)

At the Hong Kong Ministerial, WTO members agreed to establish a taskforce that would provide recommendations on how to operationalise AfT and investigate further into how AfT funds could best contribute to pro-poor development. This body was made up of 13 WTO members, 5 developed countries and 7 developing countries. The coordinators of the ACP and the African groups in WTO were included among these countries. In the recommendation report delivered in July 2006, developing countries' perspectives, particularly on the issue of financing, is present. While donors saw the opportunity to relabel already pledged ODA funds as Aid for Trade, developing countries insisted on the need for all AfT funding to be new and not recycled. Point $\mathrm{C}$ of the task force's report recommended the following:

Additional, predictable, sustainable and effective financing is fundamental for fulfilling the Aid-for-Trade mandate. The effectiveness of the following recommendations for operationalizing Aid for Trade requires substantial additional targeted resources for trade-related programmes and projects as pledged at the WTO's Hong Kong Ministerial Conference, and against the background of the broader international commitment at the UN's Monterrey Conference and the G8 Summits in Gleneagles and St. Petersburg to significantly scale up development assistance by 2010.

(AfT Task Force 2006)

Likewise, the importance of financing for the adjustment costs of trade liberalisation was reiterated in the Khartoum declaration (ACP 2006: 16):

[...] development should constitute the cornerstones of EPAs and therefore call for enhanced development cooperation, including increased and fast disbursement of requisite resources to enable ACP States to benefit effectively from EPAs. We further call for additional finance and appropriate financial instruments that are necessary for assisting in addressing adjustment costs and building human, institutional and industrial capacities and infrastructure for trade as spelt out in the report of the WTO Task Force on Aid-for-Trade adopted by the WTO Council in October 2006.

In sum, the AfT initiative, as it materialised within the WTO, shows that developing countries, at least to a certain extent, have been able to collaborate to influence the politics of a major WTO initiative. In doing so they have acted together in coalitions of the weak to alleviate the influence of more powerful states and relied on the generally accepted argument that global trade must serve development purposes. Most notably, the AfT 
initiative is evidence of developing states' influence on global trade governance, which goes beyond the right to veto, something that would be in line with a movement from domination towards non-domination.

Yet the existence of power-mediating structures within the WTO does not imply an end to domination in global trade negotiations. As many scholars have pointed out, the difficulty in concluding the Doha-round negotiations has led wealthier states to seek bilateral and regional trade agreements with developing countries, conventionally known as Preferential Trade Agreements (PTAs) (Hartman 2013). Next, we consider the extent to which the AfT initiative has reduced institutional dominance in that arena.

\section{From WTO to Regional Trade Agreements: Regaining control of the trade agenda?}

According to Wilkinson (2017) the current weakening of trade multilateralism is affecting developing countries the most. Many scholars argue that in PTA negotiations 'traditional' factors like market size and asymmetric bargaining power matter more than in the multilateral setting (Allee and Elsig 2016; Meunier and Nicolaidis 2006; Hurt et al. 2013). In the words of Wilkinson (2017) the stalemate in the WTO 'better enables the industrialized states to regain control of a trade agenda'. According to these scholars, the breakdown of trade multilateralism has enabled developed states to pursue their interests more effectively through PTAs where 'negotiations usually involve classic structural conditions of weak states trying to negotiate with the strong' (Lee 2012). The growing powers of developing countries creates a dilemma. Their resistance in WTO leads developed countries to bypass the multilateral system and provide room for their interests to win through in PTA negotiations. In other words, the potential for institutional dominance is more acute in these fora.

Following the collapse of the Doha-negotiations, AfT figured increasingly in PTA negotiations. One example is AfT's prominent role in the negotiations of the Economic Partnership Agreement (EPA) between the EU and West Africa (ECOWAS EPA). The EPA involved trade liberalisation of goods and services in conformity with the trade rules of the WTO. Trade liberalisation creates adjustment costs resulting from lost tariff revenues and investments in infrastructure. One of the central points of contention in the negotiations was the extent to which the EU would provide funds to compensate West Africa for the fiscal and economic adjustments they would have to make to implement the ECOWAS EPA (Khadiagala 2012; Langan and Price 2015; Meyn 2012; Makhan 2012). While the EU insisted that trade liberalisation and financing were two separate issues, West African negotiators clearly voiced a demand for long-term financing of the EPA as a pre-condition for entering the agreement (Meyn 2012).

Negotiations of the ECOWAS EPA commenced in 2006. An early proposal for an EPA was turned down by West Africa in 2007 due to the lack of a concrete finance mechanism (Langan and Price 2015). As negotiations progressed, West Africa, led by the ECOWAS and UEMOA Commissions, developed an EPA Development programme (conventionally known as PAPED from the French acronym), which would ensure that the EPA would 
align with the development ambitions of the region. The PAPED was a home-grown initiative elaborated for the region through a broad participatory approach (Thomas 2009). The PAPED justified the need for development funds accompanying the EPA in order to mitigate the negative impacts of the EPA. For the West African negotiators these funds were a condition for moving forward in the negotiations:

Dr Obideyi [Director of trade of ECOWAS] said the two parties were working to resolve the divergence issues, saying that many of the differences between the partners had been reduced to about four main issues with the development funding a key one. He said the position of the Heads of State of ECOWAS was clear on the development funding arrangement, saying the EC Development Fund was a priority and conditionality for signing the EPA and that the experts would not compromise on the position. The funding arrangement, he said, remained a key point in the negotiation process with the ECOWAS Heads of State seeking a certain threshold of funding which the European Union was yet to give a positive response to.

(Modern Ghana 2011)

Civil Society organisations, which had been active in voicing their opinions during the negotiations spoke out in support of the West African negotiators (see also Del Felice 2014; Siles-Brügge 2014; Trommer 2011 for accounts of civil society influence on the negotiations):

We support the statement made by the ECOWAS' Director of Trade that a proper and binding PAPED is a PRE-CONDITION for an ECOWAS EPA and hold West African officials to this commitment.

(West African Civil Society Platform 2011)

In April 2010 ECOWAS requested €9.5 billion of AfT and private sector development assistance (PSD) from the EU to finance PAPED (ECOWAS 2010). According to Langan and Price (2015: 268) Nigeria was fronting the argument that the EPA would lead to negative effects in the region which would have to be compensated for by the EU through AfT support to the PAPED. The eventual EU pledge of $€ 6.5$ billion to fund the PAPED represented a breakthrough for the West African negotiators:

The EU currently estimates that funds available for PAPED related activities from all of its financing instruments over the next five years amount to at least 6.5 billion Euros. Total aid for trade to West Africa from all donors can be projected to exceed 12 billion US dollars in the same period. Thus the EU expects to be in a position to support the PAPED to a very substantial extent.

(Council of the EU 2010)

However, it was still uncertain whether the funds that the EU pledged in May 2010 were merely a restatement of funds that were already pledged under the European Development Fund (EDF). The EU's statement was not enough to make West African negotiators sign 
the ECOWAS EPA at that stage. In March 2014 the EU released a new statement where they made a new commitment to fund the PAPED for the coming period 2015-2020:

Support to the PAPED from the EU, its Member States and the European Investment Bank (EIB) during the period 2010-2014 has already exceeded the Council's commitment of 6.5 billion euros and reached more than 8.2 billion euros in funding. In the next years, the EU stands committed to again provide at least 6.5 billion euros for activities linked to the PAPED in West Africa for the 2015-2020 period from all its financing instruments, those of its Member States and the EIB.

(Council of the EU 2014)

With this move, West African negotiators were satisfied with the level of funding of the PAPED (see also Langan and Price 2015 for a more thorough discussion of this decision):

On the basis of the consensual results reached by the Chief Negotiators on all the issues (particularly on the market access offer, the EPA Development Programme (EPADP) and the text of the Agreement), the Heads of State and Government endorse the Economic Partnership Agreement negotiated which has taken due account of the technical concerns raised.

(ECOWAS 2014)

While the question of funding for PAPED was only one of several points of contention during the final stages of the ECOWAS EPA negotiations, it serves as an illustration of the extent to which African negotiators have been able to make use of reasonable arguments to get concessions from the EU. Throughout the negotiations West African negotiators used the argument that EPAs would cause unfavourable consequences to West African states and AfT and PSD funding was necessary to be able to manage a sustainable implementation of the EPA (see also Hurt et al. 2013 for a similar argument). Eventually, the EU changed its position on keeping funding and trade negotiations as separate issues and decided to provide funding to the PAPED. This resonates with Pettit's (2010) conceptualisation of justice as non-domination in that the West African states managed to seek an un-forced cooperative solution to alleviate the possible domination of stronger states. In this case, West African states appealed to arguments regarding the need for financial instruments in order to compensate for the unwanted consequences of trade liberalisation and to build capacity for enhancing competitiveness and managed to reach reasonable support for this argument.

So far the analysis suggests that African states have made use of coalition building and norm-based arguments to gain concessions on AfT from the EU in the context of WTO as well as the regional EPA negotiations. Whereas the 'rules of the game' in global trade have not necessarily changed, African agency has influenced trade negotiations in ways moving beyond their right to veto. However, reducing political domination may or may not translate to a reduction in neo-colonial economic domination. In order to investigate this, we turn to an observable outcome of the AfT initiative, namely the extent to which AfT efforts have or have not shaped the influx of Foreign Direct Investment to Africa. 


\section{EU Aid for Trade as a tool to reshape neo-colonial trade dependence?}

In order to evaluate the extent to which AfT has reduced patterns of economic dependence or domination, we first need to define what such an outcome might look like. Drawing on Woddis (1967), Langan (2018: 64) argues that AfT initiatives may have parallels to neocolonial practices if:

[...] Western governments subsidised their own companies' 'loot' of Africa via the construction of better roads, railways and ports (thereby assisting the export of valuable goods to Europe and the USA). Aid was not necessarily a benefit to local peoples, but rather helped to perpetuate colonial patterns of trade that facilitated capital accumulation in the donor country.

Accordingly, our first hypothesis rests on the assumption that AfT is intended to promote commercial interests (domination). Indeed, the EU has, from the outset, linked AfT closely to private sector cooperation and the use of blending mechanisms to make AfT boost foreign direct investment. This is visible inter alia in the EU's communication to the Aid for Trade Task force in the WTO:

One of the issues raised in the letter of the Chairman of the Task Force on Aid for Trade to the agencies addresses the role of the private sector in identifying needs and implementing responses. The EU and its Member States consider this question very pertinent. It is the private sector that produces and distributes tradeable goods and services [...] Any Aid-for-Trade mechanism should therefore fully appreciate the role of the private sector to ensure getting real results on the ground and give particular attention to pro-poor strategies.

(European Communities and its Member states 2006)

The EU's linkage of aid to the private sector is also traceable prior to the AfT initiative, for instance in the Commission's (1996) 'The global challenge of international trade: A market access strategy' as well as the (1998) 'Strategy for private sector development'. In 2007, the EU officially launched its EU strategy on aid for trade (Council of the EU 2007a). The link between AfT and FDI becomes even more prominent in EU documents after 2007. In 2014 the Commission (2014) released the Communication 'A stronger role of the private sector in achieving inclusive and sustainable growth in developing countries'. In the updated aid for trade strategy the EU seeks to '[u]se ODA strategically as a catalyst to mobilise other public and private financial flows' and 'promote AfT to eradicate poverty in developing countries by assisting them to leverage trade and investment, strengthen inclusive, sustainable growth, create decent jobs and promote regional integration' (Council of the EU 2017). In sum, the EU's interpretation of AfT is linked to the belief that aid in combination with private sector cooperation will increase benefits for developing countries. In particular, AfT is presented as a tool by which to improve the investment climate in developing countries and thereby spur foreign direct investment. Arguably, this FDI could propel growth which would enable the host countries to counter the economic domination of the strong state (Sjursen 2017b). 
However, this commercial tie with AfT is not problematic in and of itself, but only becomes neo-colonial if EU AfT serves to primarily or disproportionately support European FDI. Indeed, the international relations literature is rich in studies that examine the assumption that some donors might use aid to their own economic ends either directly, (Alesina and Dollar 2000, Berthélemy and Tichit 2004), or via a more subtle mechanism of 'targeting' it for development purposes that may lead to positive externalities for the donor (Bermeo 2017). Some have explicitly proposed that aid is primarily used in the interest of donors to promote their own trade ties developing countries, cementing dependence (Brazys 2010; Hoeffler and Outram 2011; Hühne et al. 2014; Langan 2018). While the cross-country literature has long found that aid attracts FDI, including in Africa (Anyanwu 2012, Amusa et al. 2016, Lee and Ries 2016), Kimura and Todo (2010) have also argued that aid can have a 'vanguard effect' where aid from a particular donor country attracts FDI from that country but not from other source countries. Accordingly, our first hypothesis is that:

H1: European AfT attracts more European FDI than non-European FDI.

The alternative hypothesis (two) is that European AfT does not perpetuate colonial patterns of trade but, instead, attracts as much or more FDI from non-European sources compared to European sources. This latter effect would be evidence of European AfT reducing economic domination by encouraging a diversification of FDI sources.

H2: European AfT attracts as much or more non-European FDI than European FDI.

\section{Data and Methods}

To analyse the impact of AfT on FDI, we construct a panel of 1580 Afrobarometer sites in six countries from 2003 to 2017. Using Afrobarometer sites allows us to use aggregated site-levels controls, and we control for a number of potential confounders of FDI including the local corruption environment, urban/rural status, and demographic characteristics. The six countries are Burundi, Nigeria, Zambia, Senegal, Sierra Leone and Uganda, which are chosen due to the existence of 'Aid Information Management System' (AIMS) in those places. These data systems have been used by AidData to construct geo-referenced, projectlevel aid datasets covering nearly all donors (Peratsakis et al. 2012; AidData 2016a; AidData 2016b; AidData 2016c; AidData 2016d; AidData 2017a; AidData 2017b). This aid data is used to construct the primary explanatory variable. Following the logic of the spatial-temporal approach of Knutsen et al. (2017), we can take advantage of the temporal nature of the data to assess if a given Afrobarometer site had an 'active', 'inactive' or no AfT project in a given year. 'Active' is coded ' 1 ' for site i, time t, if an AfT project had begun at that site by that year. 'Inactive' sites are coded ' 1 ' when no AfT project had yet begun at site $i$, time $t$, but where an AfT project would begin later in the sample. Sites where no AfT project occurred over the course of the sample are coded 'o' for both active and inactive.

In addition to this simple coding, we also take advantage of the fact that our project-level aid data has information on the type of Aid for Trade project. As mentioned above, AfT falls into three broad categories: infrastructure, regulatory assistance and industry 
development. Several studies have investigated these differing aspects of AfT, finding that some types of AfT might be more effective in facilitating exports than others (Vijil and Wagner 2012). Beyond this, AfT has been critiqued for being overly broad, with many projects classified as such only being tangentially related to trade or export activities (Brazys 2013). Accordingly, we use project information to classify our AfT into infrastructure, regulatory and industry projects. We then create a second construction of the 'active' variable wherein the variable is assigned ' 1 ' once a site has at least two of the three types of AfT. Sites with multiple AfT projects are more likely to indicate an intent of promoting export-related activity in the area.

This active/inactive distinction allows for a difference-in-difference comparison wherein we can compare 'active' AfT sites not only to all sample locations, but also to those locations that would have both FDI and AfT during the sample period. This latter comparison helps to mitigate any endogenous selection effects that may occur at sites hosting both AfT and FDI. In other words, there may be other observable and unobservable characteristics that attract both AfT and FDI. By comparing the impact of AfT on FDI of 'active' sites to 'inactive' sites we can alleviate these selection effects.

Our primary outcome variable is a binary indicator that equals ' 1 ' if there is a new greenfield or expansion FDI project at site i, time t. These data are sourced from the Financial Times fDi markets database which is being used in an increasing number of political economy investigations (Gil-Pareja et al. 2013; Brazys and Regan 2017; Owen 2018). Like the AidData, this data contains both spatial and temporal information on both the timing and location of the FDI projects. This data includes 1,246 projects located at the city-level in the six study countries from 2003 to 2017. We use project events as the basis of the outcome measure as this data is verified and cross-referenced in the original fDi Markets methodology, whereas other information on project size is largely estimated and potentially biased. In order to evaluate our hypotheses, we consider separate models using indicators of EU and non-EU FDI projects, respectively.

The well-known incidental parameter problem means that it is not possible to include sitelevel fixed effects in the logit models (Lancaster 2000). Instead, our models use countryyear fixed effects with site-clustered standard errors that account for exogenous site-level shocks. The country-year fixed effects control for unobserved country-year phenomena which might otherwise influence FDI locating such as a new trade arrangement (Osnago et al. 2016), a change in government or regime (Morrissey and Udomkerdmongkol 2012), or armed conflict or unrest (Driffield et al. 2013).

In calculating our treatment area, we need to make an assumption about the geographic reach of a given aid project. While there is no a priori theoretical cut-off point, it must be large enough accommodate the precision of the data but small enough to avoid unnecessary noise. The analysis employs precision code ' 3 ' in the AidData, which is the 'district' or 'administrative 2' level. Likewise, the FDI data relies on city-level locations which should be roughly $25 \mathrm{~km}$. Most studies using this approach have settled on $50 \mathrm{~km}$ as the ideal distance for evaluation (Knutsen et al. 2017) and, given our use of 'district-level' AidData, this seems appropriate. Accordingly, the primary analysis below uses that distance. However, we explore other distances in the robustness checks. A final issue is that local 
FDI is likely to cluster, following well-established studies of economic geography (Shatz and Venabels 2000). Accordingly, we include a measure of the cumulative stock of FDI in our models. However, of note is the fact that our data is temporally truncated at 2003. This means our variable on the existing FDI stock as this variable will be 'o' in 2003 at all sites. Accordingly, in the robustness checks, we also allow for a 'burn in' for existing FDI of 2 years and evaluate our model on the data between 2005 and 2017. Full information on data sources and summary statistics is available in Supplementary Appendix Table 1.

\section{Results}

The results are presented in Table 1 . For ease of interpretation we present odds ratios in lieu of coefficient from our logistic regression models, noting that a value greater than one means an increased likelihood of the outcome, while a value less than one means a decreased likelihood. However, the difference-in-differences reported are differences in the logit coefficients. We also only present the results on our key variables of interest and the difference-in-difference. Full results on the control variables are available in Appendix Table 7 .

Table 1: EU AfT and EU and Non-EU FDI

\begin{tabular}{|c|c|c|c|c|}
\hline VARIABLES & (1) EU Any & $\begin{array}{r}\text { (2) non-EU } \\
\text { Any }\end{array}$ & $\begin{array}{l}\text { (3) EU } \\
\text { Multiple }\end{array}$ & $\begin{array}{l}\text { (4) non-EU } \\
\text { Multiple }\end{array}$ \\
\hline Active & $\begin{array}{r}3.918^{* * *} \\
(0.568)\end{array}$ & $\begin{array}{r}4.423^{\star * *} \\
(0.757)\end{array}$ & $\begin{array}{r}2.102^{* * *} \\
(0.209)\end{array}$ & $\begin{array}{r}1.620^{\star * *} \\
(0.146)\end{array}$ \\
\hline Inactive & $\begin{array}{r}4.399^{* * *} \\
(0.545)\end{array}$ & $\begin{array}{r}4.733^{\star * *} \\
(0.752)\end{array}$ & $\begin{array}{r}0.0393^{* * *} \\
(0.0391)\end{array}$ & $\begin{array}{l}0.438^{* * *} \\
(0.0864)\end{array}$ \\
\hline FDI Stock & $\begin{array}{r}16.16^{* * *} \\
(1.326)\end{array}$ & $\begin{array}{r}14.68^{* * *} \\
(0.902)\end{array}$ & $\begin{array}{r}18.97^{\star \star *} \\
(1.519)\end{array}$ & $\begin{array}{r}15.88^{* * *} \\
(0.935)\end{array}$ \\
\hline Constant & $\begin{array}{r}0.0134^{* * *} \\
(0.0103)\end{array}$ & $\begin{array}{r}0.000354^{* * *} \\
(0.000283)\end{array}$ & $\begin{array}{r}0.00896^{* * *} \\
(0.00692)\end{array}$ & $\begin{array}{r}0.000240^{* * *} \\
(0.000187)\end{array}$ \\
\hline Observations & 18,751 & 21,913 & 18,751 & 21,913 \\
\hline Baseline Controls & YES & YES & YES & YES \\
\hline Country-Year Dummies & YES & YES & YES & YES \\
\hline Difference in difference & -0.116 & -0.0677 & $3.978^{\star \star \star}$ & $1.308^{* * *}$ \\
\hline Chi2 active-inactive $=0$ & 0.689 & 0.303 & 15.93 & 38.12 \\
\hline$p$ value & 0.406 & 0.582 & 0.000 & 0.000 \\
\hline
\end{tabular}

Robust se in parentheses

${ }^{* * *} p<0.01,{ }^{* *} p<0.05,{ }^{*} p<0.1$

There are several interesting features of our results. First, when considering our treatment variable as any local EU AfT project (models 1 and 2), we see no statistically significant difference between active and inactive sites for either EU (model 1) or non-EU (model 2) FDI. However, it is interesting to note that the odd ratios are greater than 1 and statistically significant for both 'active' and 'inactive' in both models. This suggests that single types of 
EU AfT projects head to Afrobarometer sites which are multiple times more likely to receive FDI than Afrobarometer sites which never receive AfT.

However, our results are starker when changing our treatment to indicate Afrobarometer sites as 'active' only when receiving multiple AfT projects (models 3 and 4). In the case of both EU (model 3) and non-EU (model 3) FDI, we see a positive and statistically significant difference between active and inactive sites in attracting FDI. Moreover, as indicated by the odds ratios less than 1 on the 'inactive' variables, these sites were substantially and significantly less likely to receive FDI compared to non-AfT sites. This suggests that sites that received multiple EU AfT projects were comparatively needy in terms of attracting FDI vis-à-vis sites which never received AfT.

In terms of our hypotheses 1 and 2, we see that the impact of AfT on EU and non-EU FDI, in broad strokes, is substantively similar. In both instances, the presence of multiple EU AfT projects leads the site from being less likely to more likely to attract FDI, compared to non-AfT sites. However, there is some divergence in the magnitude of this effect. Whereas an inactive site goes from being roughly 25 times less likely to attract FDI to just over 2 times more likely to receive EU FDI, for non-EU FDI the change is only from about 2.3 times less likely to 1.6 times more likely. In other words, multiple active AfT projects makes sites that were much less likely to receive EU FDI projects about as likely to receive EU or non-EU FDI projects. Thus, the comparative difference stems more from the previous absence of EU FDI when the sites were 'inactive', rather than a dominating presence once the sites became 'active'. Accordingly, we interpret these results as being consistent with hypothesis 2, that EU AfT attracts EU and non-EU FDI at similar rates and thus is not increasing EU economic dominance.

\section{Robustness}

We submit our core results to several robustness checks and extensions. We discuss the substantive implications of these findings here with full results tables available in the appendix. The first checks consider the results using 25km (Appendix Table 2) and $75 \mathrm{~km}$ (Appendix Table 3) spatial join distances, respectively. In both of these instances, the substantive results of models 3 and 4 above are maintained, with multiple active EU AfT projects making sites more likely to attract both EU and non-EU FDI, compared to inactive sites.

Next, we take advantage of the full count data to modify our dependent variable to siteyear counts of EU and non-EU FDI projects, respectively, rather than site-year binary indicators. There is a large proportion of 'o' site-year observations in these variables. There are several ways to deal with a concentration of values at the limit, but, given the count nature and over dispersion of the outcome variable, a zero-inflated negative binomial estimation strategy is most appropriate. Theoretically it is plausible that some factors might both influence whether or not a site receives FDI at all in a given year, but also the number of FDI projects the site receives. Alternatively, other factors may only theoretically influence the number of sites at a project that otherwise receives projects. Indeed, the existing stock of FDI projects is likely to influence the number of FDI projects a site receives in a particular year but also if a site receives any FDI. Conversely, an 
indicator of whether a site is urban is likely to influence if the site receives any FDI but, as a simple binary indicator which includes no information on the size of the urban area, is unlikely to help explain the number of FDI projects received. Zero-inflated negative binomial is a two-step process by which the first stage uses a logit estimator to assess the probability of a site-year receiving no FDI projects, while the second stage uses negative binomial to assess the count of FDI projects at the site in that year.

The first stage determinants are site characteristics including the existing FDI stock, whether the site is urban, the level of local corruption at the site, and mean demographic features of local respondents including sex and age. The second stage includes countryyear fixed effects and the existing FDI stock, but now includes the 'active' and 'inactive' variables, but not the other site characteristics. Interpreting the difference between the coefficients on these 'active' and 'inactive' variables is thus informative of how many more/less FDI projects an 'active' site receives compared to an 'inactive' site, with both compared to a site with no AfT projects.

The substantive results from these count models, presented in Appendix Table 4, are similar to those above. For both EU (model 1) and non-EU (model 3) FDI, multiple active EU AfT projects increases the count of FDI projects, given there was already an FDI project at the site, compared to inactive AfT sites. While the active/inactive difference-indifference is positive and significant for both EU and non-EU FDI, the substantive result is larger in the EU case. Multiple, active AfT projects increase the log count of EU FDI projects (model 1) at a site by 3.345 , or $370 \%$, of the sample mean of 0.901 , compared to inactive AfT sites, given there was at least one FDI project. In contrast, multiple, active EU AfT projects increase the log count of non-EU FDI project (model 3) by only 0.341 , or 26\%, of the sample mean of 1.320 .

Our next robustness check draws on previous work on AfT that has suggested a lag between project timing and an observable outcome (Brazys 2010). Accordingly, in Appendix Table 4, we lag our AfT measure by one (models 5 and 6) and two (models 7 and 8) years, respectively. We also estimate base models (9 and 10) with no Afrobarometer site controls, as well as models with additional site-level controls (models 11 and 12) including additional corruption measures, as well as aggregated household-level measures of cash poverty. Finally, we omit the first two years of our data to 'burn in' existing FDI stocks (models 13 and 14). In all of these instances, the substantive findings are similar to those in the main models above.

Finally, given the spatial nature of our data there is a possibility that our outcome process is spatially auto-regressive. Unfortunately, given dimensions of our panel and the computing resources available to us we are unable to estimate Moran's I or implement spatial lag or spatial error models on our full panel data. As an alternative, we collapse the residuals from our main regressions by Afrobarometer site and estimate Moran's I at various distance bands, as shown in Appendix Table 5. While the spatial correlations coefficients are relatively small, they do indicate the possibility of spatial autocorrelation in the residuals. Accordingly, we run both OLS and models which incorporate a spatial lag 
on site-level collapsed data in Appendix Table 6.3 In both instances, the OLS and Spatial Lag models return nearly identical results, suggesting that spatial autocorrelation does not substantially influence our results. While it is not possible to directly compare these results to the panel results above, sites with a high proportion of multiple active EU AfT project years again attract both more EU (models 1 and 2) and non-EU (models 3 and 4) FDI. Also, again in all instances, the coefficient on 'inactive' is negative and significant, suggesting that these sites which would receive multiple EU AfT projects, but hadn't yet, were less likely to receive FDI vis-à-vis non-AFT sites.

\section{Conclusion}

The establishment of the Doha development round in WTO illustrates the recognition that global trade needs reform in order to deliver more development-friendly policies. While the Doha negotiations are deadlocked, the establishment of the Aid for Trade initiative has been seen as a victory for developing countries. Yet despite this impression, it remains unclear whether the AfT project has changed either the institutional dominance and economic dependence many argue exist in the global trading order.

Our findings point to some success in the AfT initiative's ability to level the politics of the global trade regime. On the one hand, our analysis suggests that African states have made use of coalition building and arguments regarding the unfair consequences of trade liberalisation to gain concessions on AfT from the EU both in the multilateral setting and in regional PTA negotiations. While many scholars argue that the move from multilateralism to PTA negotiations mostly affects developing countries, we have used the case of the negotiations of the ECOWAS EPA to illustrate that African agency has moved beyond the right to veto, and that African states have been able to partially succeed in their negotiation strategy of leveraging new AfT funds from the EU. However, there is no evidence of a significant change in the rules of the game either at the multilateral level or in PTAs. The increasingly neoliberal orientation of EU trade policy has been continued without significant modifications (Siles-Brügge 2014).

Beyond reducing political or institutional dominance, our analysis also finds support that the EU's AfT initiative does not exacerbate economic dependence. By operationalising neo-colonial AfT as that which attracts FDI from the same source as the aid, we see that European AfT appears to promote both European and non-European economic ties. Combining local data from six African countries with a spatial-temporal, difference-indifference approach, we find that Afrobarometer sites with multiple, active, European AfT projects have an increased likelihood of attracting FDI projects, both from European and non-European sources, compared to 'inactive' AfT sites, i.e. a site where AfT would, but had not yet arrived. While we find some evidence that the comparative magnitude of this effect is larger for European FDI, the finding stems from the fact that these 'inactive' AfT sites were much less likely to attract EU FDI than non-EU FDI compared to sites that never received any EU AfT. However, after receiving multiple active EU AfT projects, these sites were more likely to attract both EU and non-EU FDI at comparable rates, again

3 Where all variables are collapsed on their mean values, by site. 
compared to sites which never received EU AfT. These core findings are robust to a number of different estimation choices.

Our findings are relevant for the debate regarding a possible 'pragmatist turn' in EU foreign policy (Juncos 2017). The new EU global strategy and the coining of principled pragmatism as the new operating principle for EU foreign policy indicates that the EU increasingly seeks to square a norm-based policy with concerns for its own interests:

our interests and values go hand in hand. We have an interest in promoting our values in the world. At the same time our values are embedded in our interests.

(Global Strategy, quoted in Sjursen 2017a)

Similar statements can be observed in the realm of trade specifically. For instance, the UK secretary of state for international development stated in 2013:

Building economic growth and creating jobs is not only good for developing countries, it benefits Britain too, by creating new markets for British businesses to invest in.

(Greening 2013)

Yet while EU AfT does appear to attract EU FDI, it also makes sites more attractive to nonEU FDI. Whether or not this is an intended or unintended consequence of principled pragmatism, the fact ultimately remains that such an outcome is unlikely to reinforce, if not likely to reduce, the EU's economic dominance of its AfT partners. 


\section{References}

Allee, T. and M. Elsig (2016) 'Why do some international institutions contain strong dispute settlement provisions? New evidence from preferential trade agreements', The Review of International Organizations, 11(1), 89-120.

Alesina, A. and D. Dollar (2000) 'Who gives foreign aid to whom and why?', Journal of Economic Growth 5(1), 33-63.

Anyanwu, J.C. (2012) 'Why does foreign direct investment go where it goes? New Evidence From African Countries', Annals of Economics \& Finance 13(2): 425-462.

Amusa, K., N. Viegi and N. Monkam (2016) 'The nexus between foreign direct investment and foreign aid: an analysis of sub-Saharan African countries', African Finance Journal 18(2): 45-68.

Bermeo, S. (2017) 'Aid allocation and targeted development in an increasingly connected world', International Organisation 71 (fall): 735-766.

Berthélemy, J. C. and A. Tichit (2004) 'Bilateral donors' aid allocation decisions-a three dimensional panel analysis', International Review of Economics \& Finance 13(3): 253274.

Brazys, S. and S. Lightfoot (2016) 'Europeanisation in Aid for Trade: the impact of capacity and socialisation', European Politics and Society 17(1): 120-135.

Brazys, S. (2010) 'Race to give? The selective effectiveness of United States trade capacity building assistance', Review of International Political Economy 17(3): 537-561.

Brazys, S. (2013) 'Evidencing donor heterogeneity in Aid for Trade', Review of International Political Economy 20(4): 947-978.

Brazys, S., and A. Regan (2017) 'The politics of capitalist diversity in Europe: Explaining Ireland's divergent recovery from the Euro crisis', Perspectives on Politics 15(2): 411427.

Caporaso, J.A. (1978) 'Dependence, dependency, and power in the global system: A structural and behavioral analysis', International Organisation 32(1): 13-43.

Del Felice, C. (2014) 'Power in discursive practices: The case of the stop EPA campaign', European Journal of International Relations 20(1): 145-167. .

Driffield, N., C. Jones and J. Crotty (2013) 'International business research and risky investments, an analysis of FDI in conflict zones', International business review, 22(1), 140-155.

Easterly, W. (2001) 'The lost decades: Developing countries' stagnation in spite of policy reform 1980-1998', Journal of Economic Growth 6: 135-157.

Eriksen, E.O. (2016) 'Three conceptions of global political justice', GLOBUS Research Paper 1/2016. Available at: https://papers.ssrn.com/sol3/papers.cfm?abstract id=2878745.

Føllesdal, A. (2016) ‘Toward a more just WTO: Which justice, whose interpretation?' in R. Howse, H. Ruiz Fabri, Q. Zang, O.K. Fauchald and G. Ulfstein (eds), The Legitimacy of International Trade Tribunals. Cambridge: Cambridge University Press.

Gil-Pareja, S., R.L. Vivero and J. Paniagua (2013) 'The effect of the great recession on foreign direct investment: global empirical evidence with a gravity approach', Applied Economics Letters 20(13): 1244-1248. 
Hurt, S. (2003) 'Co-operation and coercion? The Cotonou Agreement between the European Union and ACP states and the end of the Lomé Convention', Third World Quarterly 24(1): 161-76.

Hurt, S., D. Lee and U. Lorentz-Carl (2013) 'The argumentative dimension to the EUAfrica EPAs', International Negotiation 18(1): 67-87.

Hartman, S.W. (2013) 'The WTO, the Doha round impasse, PTAs, and FTAs/RTAs', The International Trade Journal 27(5): 411-430.

Hühne, P., B. Meyer and P. Nunnekamp (2014) 'Does aid for Trade from the North, promote South-South trade?' Applied Economics Letters 21(17): 1230-1233.

Hoeckman, B. (2002) 'Strengthening the global trade architecture for development: The post Doha agenda', World Trade Review 1(1): 23-45.

Hoekman, B. and S. Prowse (2005) 'Economic policy responses to preference erosion: From trade as aid to aid for trade', World Bank Policy Research Working Paper 3721.

Hoeffler, A. and V. Outram (2011) 'Need, merit, or self-interest: What determines the allocation of aid?', Review of Development Economics 15(2): 237-250.

Hoogvelt, A. (2006) 'Globalization and post-modern imperialism', Globalizations 3(2): 159-174.

Juncos, A.E. (2017) 'Resilience as the new EU foreign policy paradigm: A pragmatist turn?', European security, 26(1), 1-18.

Kimura, H. and Y. Todo (2010) 'Is foreign aid a vanguard of foreign direct investment? A gravity-equation approach', World Development 38(4): 482-497.

Khadiagala, G. M. (2012) ‘Africa and Europe: Ending a dialogue of the deaf?', in A. Adebajo and K. Whiteman (eds.), The EU and Africa: From Eurafrique to Afro-Europa, London: Hurst and Company.

Krugman, P. (1981) 'Trade, accumulation, and uneven development', Journal of Development Economics 8(2): 149-161.

Knutsen, C.H., A. Kotsadam, E.H. Olsen and T. Wig (2017) 'Mining and local corruption in Africa', American Journal of Political Science 61(2): 320-334.

Holden, P. (2014) 'Tensions in the discourse and practice of the European Union's Aid for Trade', Contemporary Politics, 20(1), 90-102.

Lancaster, T. (2000) 'The incidental parameter problem since 1948', Journal of econometrics, 95(2), 391-413.

Langan, M. (2016) The moral economy of EU association with Africa. London and New York: Routledge.

Langan, M. (2018) 'Neo-colonialism and donor interventions: Western aid mechanisms', in Neo-Colonialism and the Poverty of 'Development' in Africa, 61-88, London: Palgrave Macmillan.

Langan, M. and S. Price (2015) 'Extraversion and the West African EPA Development Programme: Realising the development dimension of ACP-EU trade?', Journal of Modern African Studies 53(3): 263-287.

Langan, M. and J. Scott (2014) 'The Aid for Trade charade', Cooperation and Conflict 49 (2): 143-161. 
Lam, A.S. (2008) 'Aid for Trade and the European Development Fund', in D. Njinkeu and H. Cameron (eds) Aid for Trade and Development. Cambridge: Cambridge University Press.

Lee, D. (2012) 'Global trade governance and the challenges of African activism in the Doha Development Agenda negotiations', Global Society 26(1): 83-101.

Lee, H.H., and J. Ries (2016) 'Aid for trade and greenfield investment', World Development 84: 206-218.

Luke, D. and L. Bernal (2011) 'Rethinking the governance of Aid for Trade', in C. D. Birkbeck (ed.) Making Global Trade Governance Work for Development. Cambridge: Cambridge University Press.

Mahler, V.A. (1994) 'The Lomé convention: Assessing a north-south institutional relationship', Review of International Political Economy 1(2): 233-256.

Meyn, M. (2012) 'An anatomy of the Economic Partnership Agreements', in Adebajo, A. and K. Whiteman (eds) The EU and Africa: From Eurafrique to Afro-Europa. London: Hurst and Company.

Makhan, D. (2012) 'The EU's coordination dilemma: Linking trade and development in the ACP-EU Economic Partnership Agreements and Aid for Trade', in S. Gänzle, S. Grimm and D. Makhan (eds) The European Union and global development. An 'enlightened' superpower in the making? Basingstoke: Palgrave McMillan.

Meunier, S., and K. Nicolaïdis (2006) 'The European Union as a conflicted trade power', Journal of European Public Policy, 13(6): 906-925.

Morrissey, O. and M. Udomkerdmongkol (2012) 'Governance, private investment and foreign direct investment in developing countries', World development, 40(3), 437445 .

Murray-Evans, P. (2019) Power in North-South trade negotiations. Making the European Union's Economic Partnership Agreements. London: Routledge.

Onwuka, Ralph I. (1989) 'Beyond Lomé III: Prospects for symmetrical EurAfrican relations', in Ralph I. Onwuka and Timothy M. Shaw (eds) Africa in the World System in the 1990s. New York, NY: St Martin's Press.

Osnago, A., Rocha, N., \& Ruta, M. (2016). Do Deep Trade Agreements Boost Vertical FDI?. The World Bank Economic Review, 3o(Supplement_1), S119-S125.

Owen, E. (2018) 'Foreign Direct Investment and elections: The impact of Greenfield FDI on incumbent party reelection in Brazil', Comparative Political Studies 52(4): 613-645.

Peratsakis, C., J. Powell, M. Findley, J. Baker and C. Weaver (2012) 'Geocoded activitylevel data from the government of Malawi's Aid Management Platform', Washington D.C. AidData and the Robert S. Strauss Center for International Security and Law.

Pettit, P. (2010) 'A republican law of peoples', European Journal of Political Theory 9(1): 70-94.

Schott, J.J., and J. Watal (2000) 'Decision making in the WTO', in J.J. Schott (ed.) The WTO after Seattle. Washington, DC: Institute for International Economics.

Shatz, H.J., and A. Venables (2000) 'The geography of international investment', Policy, Research working paper, no. WPS 2338. Washington, DC: World Bank.

Shaw, T.M. (1979) 'EEC-ACP interactions and images as redefinitions of EurAfrica: Exemplary, exclusive and/or exploitative?', Journal of Common Market Studies 18: 135-159. 
Sjursen, H. (2017a) 'Principles in European Union Foreign Policy', in C. Hill, M. Smith, and S. Vanhoonacker (eds) International relations and the European Union. Oxford: Oxford University Press.

Sjursen, H. (2017b) 'Global justice and foreign policy: The case of the European Union', GLOBUS Research Paper 2/2017. Available at: https://papers.ssrn.com/sol3/ papers.cfm?abstract id=2990461.

Siles-Brügge, G. (2014) Constructing European Union trade policy. A global idea of Europe. Basingstoke: Palgrave Macmillan.

Stiglitz, J. (2002) Globalization and Its Discontents. New York: Norton.

Trommer, S. (2011) 'Activists beyond Brussels: Transnational NGO strategies on EU-West Africa trade negotiations', Globalizations 8(1): 113-26.

Therien, J.P. (1999) 'Beyond the North-South divide: The two tales of world poverty', Third World Quarterly 20(4): 723-742.

Vijil, M., and L. Wagner (2012) 'Does aid for trade enhance export performance? Investigating the infrastructure channel', The World Economy 35(7): 838-868.

Vigrestad, J. (2018) Partnerships for sustainable trade? GLOBUS Report 2/2018. Available at: https://www.globus.uio.no/publications/reports/2018/globus-report-2online.pdf.

Walleri, R. D. (1978) 'Trade dependence and underdevelopment: A causal-chain analysis', Comparative Political Studies 11(1): 94-127.

Wilkinson, R. (2017) 'Back to the future: 'Retro' trade governance and the future of the multilateral order', International Affairs 93(5): 1131-1147.

Woddis, J. (1967) An introduction to neo-colonialism. London: Lawrence and Wishart.

\section{Official documents, databases and press articles}

ACP (2006) Khartoum Declaration. 8 December 2006. ACP/28/057/o6 Final. Available at: http://webcache.googleusercontent.com/search?q=cache:http://www1.uneca.org/ Portals/atpc/CrossArticle/1/reference documents/ACP-Khartoum Declaration .pdf.

African Group at WTO (2006) Communication from Benin on behalf of the African Group. 9 June $2006 \mathrm{WT} / \mathrm{AFT} / 21)$.

AidData.2016a.DRC-AIMS_GeocodedResearchRelease_Level1_v1.3.1 geocoded dataset. Williamsburg, VA and Washington, DC: AidData.

AidData. 2016b. NigeriaAIMS_GeocodedResearchRelease_Level1_v1.3.1 geocoded dataset. Williamsburg, VA and Washington, DC: AidData.

AidData. 2016c. UgandaAIMS_GeocodedResearchRelease_Level1_v1.4.1 geocoded dataset. Williamsburg, VA and Washington, DC: AidData.

AidData. 2016d. SenegalAIMS_GeocodedResearchRelease_Level1_v1.5.1 geocoded dataset. Williamsburg, VA and Washington, DC: AidData.

AidData. 2017a. BurundiAIMS_GeocodedResearchRelease_Level1_v1.o geocoded dataset. Williamsburg, VA and Washington, DC: AidData.

AidData. 2017b. SierraLeoneAIMS_GeocodedResearchRelease_Level1_v1.o geocoded dataset. Williamsburg, VA and Washington, DC: AidData. 
Aid for Trade Task Force (2006) Recommendations of the task force on aid for trade, 27 July 2006.

Commission (1996) The global challenge of international trade: A market access strategy. Brussels: European Commission.

Commission (1998) Strategy for private sector development. Brussels: European Commission.

Commission (2014) A stronger role of the private sector in achieving inclusive and sustainable growth in developing countries. Brussels: European Commission.

Council of the EU (2017) Aid for Trade Report 2017 Available at: https://ec.europa.eu/europeaid/sites/devco/files/report-aid-for-traid-2017-finalwith-stories en o.pdf

Council of the EU (2014) Council Conclusions on West Africa's EPA Development Programme (PAPED). Brussels: 17 March 2014 Available at: https://www.consilium. europa.eu/media/28728/141593.pdf

Council of the EU (2010) Council Conclusions - EPA Development Programme (PAPED). Available at: https://data.consilium.europa.eu/doc/document/ST-9634-2010-INIT/ en/pdf.

Council of the EU (2007a) Aid for Trade Strategy. 14470/07

Council of the EU (2007b) Council Conclusions on aid for trade. 9555/o7. Available at: http://trade.ec.europa.eu/doclib/docs/2007/september/tradoc 135917.pdf

ECOWAS (2014) Final communique: Forty-fifth ordinary session of the authority of ECOWAS heads of state and government. Available at: https://www.ecowas.int/wpcontent/uploads/2015/02/45th-ECOWAS-Summit-Ghana-10-Dec-20141.pdf

ECOWAS (2010) Draft proposal for PAPED. 23 April 2010.

European Communities and its Member states (2006) Engaging the private sector on aid for trade. 24 May 2006. World Trade organisation. WT/AFT/W/14.

Greening, J. (2013) 'Global trade can help us end the need for aid'. 15 July. Available at: https://www.gov.uk/government/speeches/justine-greening-global-trade-can-helpus-end-the-need-for-aid.

Modern Ghana (2011) 'ECOWAS-EU EPA Negotiations not Stalled -ECOWAS Official'. 28 November. Available at: https://www.modernghana.com/news/363634/ecowas-euepa-negotiations-not-stalled-ecowas-official.html

Moulds, J. (2015) 'EU trade agreements threaten to crush Kenya's blooming flower trade'. 16 January. Available at: https://www.theguardian.com/sustainable-business/2015/ jan/16/kenya-flower-trade-eu-pressure

Thomas, G. (2009) “Delivering the goods” on Aid for Trade: A TNI interview with the UK

Minister for Trade and Development Gareth Thomas' Trade Negotiation Insights 10(9). 29 April 2009.

West Africa Civil Society Platform (2011). 'Joint statement by the West African Civil Society Platform’. Available at: http://www.twnafrica.org/jointstatement.html.

WTO (2005) Hong Kong Ministerial Declaration. WT/MIN(05)/DEC. 22 December 2005. Available at: https://www.wto.org/english/thewto e/minist e/mino5 e/final text e.htm. 


\section{Appendix}

Appendix Table 1: Summary Statistics at $50 \mathrm{~km}$ by Cluster

\begin{tabular}{|c|c|c|c|c|c|c|}
\hline Variable & Source & Max & Min & Mean & Std Dev. & Observations \\
\hline FDI EU Count & www.fdimarkets.com & 13 & 0 & 0.357 & 1.256 & 23,700 \\
\hline $\begin{array}{l}\text { FDI non-EU } \\
\text { Count }\end{array}$ & www.fdimarkets.com & 26 & 0 & 0.820 & 2.577 & 23,700 \\
\hline FDI EU Binary & www.fdimarkets.com & 1 & 0 & 0.145 & 0.352 & 23,700 \\
\hline $\begin{array}{l}\text { FDI non-EU } \\
\text { Binary }\end{array}$ & www.fdimarkets.com & 1 & 0 & 0.219 & 0.414 & 23,700 \\
\hline Active (Any) & www.aiddata.org & 1 & 0 & 0.334 & 0.472 & 23,700 \\
\hline Inactive (Any) & www.aiddata.org & 1 & 0 & 0.071 & 0.256 & 23,700 \\
\hline Urban & $\begin{array}{c}\text { BenYishay et al. } 2017 \\
\text { http://geo.aiddata.org } \\
\text { http://www.afrobarometer.org }\end{array}$ & 1 & 0 & 0.374 & 0.478 & 23,700 \\
\hline $\begin{array}{l}\text { Corruption } \\
\text { Government } \\
\text { Officials }\end{array}$ & $\begin{array}{c}\text { BenYishay et al. } 2017 \\
\text { http://geo.aiddata.org } \\
\text { http://www.afrobarometer.org }\end{array}$ & 3 & 0 & 1.537 & 0.454 & 23,655 \\
\hline Age & $\begin{array}{c}\text { BenYishay et al. } 2017 \\
\text { http://geo.aiddata.org } \\
\text { http://www.afrobarometer.org }\end{array}$ & 68 & 19 & 34.67 & 6.209 & 23,700 \\
\hline Female & $\begin{array}{c}\text { BenYishay et al. } 2017 \\
\text { http://geo.aiddata.org } \\
\text { http://www.afrobarometer.org }\end{array}$ & 1 & 0 & 0.500 & 0.073 & 23,700 \\
\hline (In) FDI Stock & www.fdimarkets.com & 4.369 & 0 & 0.442 & 0.875 & 23,700 \\
\hline
\end{tabular}

Appendix Table 2: 25km Results

\begin{tabular}{|c|c|c|c|c|}
\hline Variables & $\begin{array}{c}\text { (1) } \\
\text { EU FDI All }\end{array}$ & $\begin{array}{c}\text { (2) } \\
\text { non-EU FDI All }\end{array}$ & $\begin{array}{c}\text { (9) } \\
\text { EU FDI Multiple }\end{array}$ & $\begin{array}{c}(10) \\
\text { non-EU FDI Multiple }\end{array}$ \\
\hline Active & $\begin{array}{l}5.672^{* \star *} \\
(1.182)\end{array}$ & $\begin{array}{l}7.515^{\star \star *} \\
(1.494)\end{array}$ & $\begin{array}{l}4.199^{* * *} \\
(0.617)\end{array}$ & $\begin{array}{l}3.196^{* * *} \\
(0.433)\end{array}$ \\
\hline Inactive & $\begin{array}{l}8.454^{* * *} \\
(1.199)\end{array}$ & $\begin{array}{l}7.819^{* * *} \\
(1.323)\end{array}$ & $\begin{array}{l}0.0648^{\star * *} \\
(0.0670)\end{array}$ & $\begin{array}{l}0.432^{* *} \\
(0.182)\end{array}$ \\
\hline FDI Stock & $\begin{array}{l}21.98^{* * *} \\
(2.820)\end{array}$ & $\begin{array}{c}21.27^{\star * *} \\
(2.253)\end{array}$ & $\begin{array}{l}31.14^{* * *} \\
(4.007)\end{array}$ & $\begin{array}{c}24.12^{* * *} \\
(2.350)\end{array}$ \\
\hline Constant & $\begin{array}{l}0.0104^{\star * *} \\
(0.0106)\end{array}$ & $\begin{array}{l}2.76 \mathrm{e}-05^{\star \star *} \\
(3.28 \mathrm{e}-05)\end{array}$ & $\begin{array}{l}0.00350^{* * *} \\
(0.00344)\end{array}$ & $\begin{array}{l}1.18 \mathrm{e}-05^{\star \star \star} \\
(1.37 \mathrm{e}-05)\end{array}$ \\
\hline Observations & 18,173 & 21,479 & 18,173 & 21,479 \\
\hline Base Controls & YES & YES & YES & YES \\
\hline Country-Year Dummies & YES & YES & YES & YES \\
\hline Difference in difference & $-0.399^{* *}$ & -0.0396 & $4.171^{* * *}$ & $2.001^{* * *}$ \\
\hline Chi2 active-inactive $=0$ & 4.449 & 0.0582 & 16.09 & 21.07 \\
\hline$p$ value & 0.0349 & 0.809 & 0.0000 & 0.0000 \\
\hline
\end{tabular}

Robust se in parentheses, ${ }^{* * *} p<0.01,{ }^{* *} p<0.05,{ }^{*} p<0.1$

Appendix Table 3: $75 \mathrm{~km}$ Results 


\begin{tabular}{|l|c|c|c|c|}
\hline Variables & $\begin{array}{c}(\mathbf{1}) \\
\text { EU FDI All }\end{array}$ & $\begin{array}{c}(\mathbf{2}) \\
\text { non-EU FDI All }\end{array}$ & $\begin{array}{c}(\mathbf{9}) \\
\text { EU FDI Multiple }\end{array}$ & $\begin{array}{c}(\mathbf{1 0}) \\
\text { non-EU FDI Multiple }\end{array}$ \\
\hline Active & $3.751^{* * *}$ & $5.557^{* * *}$ & $0.840^{*}$ & 1.011 \\
& $(0.529)$ & $(1.061)$ & $(0.0788)$ & $(0.0903)$ \\
Inactive & $5.268^{* * *}$ & $5.808^{* * *}$ & $0.184^{* * *}$ & $0.295^{* * *}$ \\
& $(0.650)$ & $(1.000)$ & $(0.0437)$ & $(0.0480)$ \\
FDI Stock & $14.57^{* * *}$ & $14.16^{* * *}$ & $16.29^{* * *}$ & $15.35^{* * *}$ \\
& $(0.984)$ & $(0.768)$ & $(1.116)$ & $(0.795)$ \\
Constant & $0.0109^{* * *}$ & $0.000219^{* * *}$ & $0.00527^{* * *}$ & $0.000121^{* * *}$ \\
& $(0.00725)$ & $(0.000148)$ & $(0.00345)$ & $(8.03 e-05)$ \\
\hline Observations & 19,005 & 22,294 & 19,005 & 22,294 \\
Year Dummies Count & YES & YES & YES & YES \\
Year Dummies Inflate & YES & YES & YES & YES \\
Country Dummies Count & YES & YES & YES & YES \\
Country Dummies Inflate & YES & YES & YES & YES \\
Difference in difference & $-0.340^{* * *}$ & -0.0443 & $1.520^{* * *}$ & $1.233^{* * *}$ \\
Chi2 active-inactive=0 & 7.150 & 0.133 & 37.68 & 67.92 \\
p value & 0.0075 & 0.715 & 0.000 & 0.000 \\
\hline
\end{tabular}

Robust se in parentheses, ${ }^{* * *} p<0.01,{ }^{* *} p<0.05,{ }^{*} p<0.1$ 
Appendix Table 4: Additional Robustness Checks

\begin{tabular}{|c|c|c|c|c|c|c|c|c|c|c|c|c|c|c|}
\hline Variables & $\begin{array}{c}(1) \\
\text { EU ZINB }\end{array}$ & $\begin{array}{c}\text { (2) } \\
\text { EU ZINB } \\
\text { Inflate }\end{array}$ & $\begin{array}{c}(3) \\
\text { non-EU } \\
\text { ZINB }\end{array}$ & $\begin{array}{c}(4) \\
\text { non-EU } \\
\text { ZINB } \\
\text { Inflate }\end{array}$ & $\begin{array}{c}(5) \\
\text { EU Lag } 1\end{array}$ & $\begin{array}{c}6) \\
\text { non-EU } \\
\text { Lag } 1\end{array}$ & $\begin{array}{c}(7) \\
\text { EU Lag } 2\end{array}$ & $\begin{array}{c}(8) \\
\text { non-EU } \\
\text { Lag } 2\end{array}$ & $\begin{array}{c}\text { (9) } \\
\text { EU No } \\
\text { Controls }\end{array}$ & $\begin{array}{c}(10) \\
\text { non-EU } \\
\text { No } \\
\text { Controls }\end{array}$ & $\begin{array}{c}(11) \\
\text { EU } \\
\text { Expanded } \\
\text { Controls }\end{array}$ & $\begin{array}{c}\text { (12) } \\
\text { non-EU } \\
\text { Expanded } \\
\text { Controls }\end{array}$ & $\begin{array}{c}(13) \\
\text { EU Post } \\
2005\end{array}$ & $\begin{array}{c}(14) \\
\text { non-EU } \\
\text { Post } \\
2005\end{array}$ \\
\hline Active & $\begin{array}{c}0.913 \\
(0.0701)\end{array}$ & & $\begin{array}{l}-0.342^{* * *} \\
(0.0346)\end{array}$ & & $\begin{array}{c}2.345^{\star \star *} \\
(0.241)\end{array}$ & $\begin{array}{l}1.875^{\star * *} \\
(0.172)\end{array}$ & $\begin{array}{c}2.388^{* * *} \\
(0.244)\end{array}$ & $\begin{array}{l}2.081^{* * *} \\
(0.198)\end{array}$ & $\begin{array}{c}2.379^{* * *} \\
(0.220)\end{array}$ & $\begin{array}{l}1.686^{* * *} \\
(0.144)\end{array}$ & $\begin{array}{l}1.964^{* * *} \\
(0.206)\end{array}$ & $\begin{array}{l}1.531^{* * *} \\
(0.156)\end{array}$ & $\begin{array}{l}1.568^{\star \star *} \\
(0.143)\end{array}$ & $\begin{array}{c}1.158 \\
(0.109)\end{array}$ \\
\hline Inactive & $\begin{array}{l}0.0322^{* * *} \\
(0.0231)\end{array}$ & & $\begin{array}{l}-0.683^{\star * *} \\
(0.1767)\end{array}$ & & $\begin{array}{c}0.0329^{\star * *} \\
(0.0327)\end{array}$ & $\begin{array}{l}0.364^{\star * *} \\
(0.0748)\end{array}$ & $\begin{array}{c}0.0455^{\star \star *} \\
(0.0339)\end{array}$ & $\begin{array}{l}0.431^{* * *} \\
(0.0670)\end{array}$ & $\begin{array}{c}0.0381^{* * *} \\
(0.0372)\end{array}$ & $\begin{array}{l}0.405^{\star * *} \\
(0.0697)\end{array}$ & $\begin{array}{c}0.0489^{* * *} \\
(0.0483)\end{array}$ & $\begin{array}{l}0.399^{* * *} \\
(0.0902)\end{array}$ & $\begin{array}{l}0.139^{* *} \\
(0.132)\end{array}$ & $\begin{array}{l}0.528^{* * *} \\
(0.117)\end{array}$ \\
\hline FDI Stock & $\begin{array}{l}1.456^{* \star *} \\
(0.0214)\end{array}$ & $\begin{array}{l}-4.649^{\star \star *} \\
(0.6053)\end{array}$ & & $\begin{array}{l}-4.023^{\star \star *} \\
(0.4470)\end{array}$ & $\begin{array}{c}18.63^{\star * *} \\
(1.468)\end{array}$ & $\begin{array}{l}15.96^{* * *} \\
(0.948)\end{array}$ & $\begin{array}{c}18.47^{\star * \star} \\
(1.451)\end{array}$ & $\begin{array}{l}15.91^{\star * *} \\
(0.939)\end{array}$ & $\begin{array}{c}22.60^{\star \star \star *} \\
(1.794)\end{array}$ & $\begin{array}{l}17.55^{\star \star \star} \\
(1.031)\end{array}$ & $\begin{array}{l}18.60^{* \star *} \\
(1.552)\end{array}$ & $\begin{array}{l}17.06^{* \star *} \\
(0.090)\end{array}$ & $\begin{array}{l}18.33^{\text {*** }} \\
(1.450)\end{array}$ & $\begin{array}{l}14.61^{\star * *} \\
(0.802)\end{array}$ \\
\hline Urban & & $\begin{array}{l}0.204^{* * *} \\
(0.0294)\end{array}$ & & $\begin{array}{l}-0.741^{* * *} \\
(0.0835)\end{array}$ & $\begin{array}{c}2.304^{* * *} \\
(0.164)\end{array}$ & $\begin{array}{c}2.084^{* * *} \\
(0.140)\end{array}$ & $\begin{array}{c}2.297^{* * *} \\
(0.163)\end{array}$ & $\begin{array}{c}2.085^{* * *} \\
(0.140)\end{array}$ & & & $\begin{array}{c}2.218^{\star * \star} \\
(0.175)\end{array}$ & $\begin{array}{c}2.151^{* * *} \\
(0.167)\end{array}$ & $\begin{array}{l}1.905^{\star \star *} \\
(0.148)\end{array}$ & $\begin{array}{l}1.907^{* * *} \\
(0.139)\end{array}$ \\
\hline $\begin{array}{l}\text { corruption_ } \\
\text { government_ } \\
\text { officials }\end{array}$ & & $\begin{array}{c}1.047 \\
(0.147)\end{array}$ & & $\begin{array}{l}0.251^{\star * *} \\
(0.0869)\end{array}$ & $\begin{array}{c}1.225^{\star *} \\
(0.0977)\end{array}$ & $\begin{array}{c}1.103 \\
(0.0773)\end{array}$ & $\begin{array}{c}1.226^{\star *} \\
(0.0979)\end{array}$ & $\begin{array}{c}1.102 \\
(0.0779)\end{array}$ & & & $\begin{array}{c}1.077 \\
(0.158)\end{array}$ & $\begin{array}{c}0.988 \\
(0.134)\end{array}$ & $\begin{array}{l}1.201^{* *} \\
(0.101)\end{array}$ & $\begin{array}{c}1.048 \\
(0.0788)\end{array}$ \\
\hline Age & & $\begin{array}{c}1.065 \\
(0.0633)\end{array}$ & & $\begin{array}{l}0.103^{* * *} \\
(0.0367)\end{array}$ & $\begin{array}{l}0.917^{* * *} \\
(0.0300)\end{array}$ & $\begin{array}{l}0.895^{\star * *} \\
(0.0255)\end{array}$ & $\begin{array}{l}0.916^{* * *} \\
(0.0299)\end{array}$ & $\begin{array}{l}0.896^{* \star *} \\
(0.0256)\end{array}$ & & & $\begin{array}{l}0.910^{* * *} \\
(0.0323)\end{array}$ & $\begin{array}{l}0.888^{* * *} \\
(0.0290)\end{array}$ & $\begin{array}{l}0.919^{* *} \\
(0.0325)\end{array}$ & $\begin{array}{l}0.890^{* * *} \\
(0.0274)\end{array}$ \\
\hline age2 & & $\begin{array}{c}0.913 \\
(0.0650)\end{array}$ & & $\begin{array}{l}-0.124^{\star * *} \\
(0.0436)\end{array}$ & $\begin{array}{l}1.096^{* *} \\
(0.0417)\end{array}$ & $\begin{array}{l}1.130^{* * *} \\
(0.0374)\end{array}$ & $\begin{array}{l}1.097^{* *} \\
(0.0416)\end{array}$ & $\begin{array}{l}1.130^{* * *} \\
(0.0375)\end{array}$ & & & $\begin{array}{l}1.108^{* *} \\
(0.0460)\end{array}$ & $\begin{array}{l}1.145^{\star \star \star} \\
(0.0438)\end{array}$ & $\begin{array}{l}1.101^{* *} \\
(0.0456)\end{array}$ & $\begin{array}{l}1.143^{* * *} \\
(0.0406)\end{array}$ \\
\hline Female & & $\begin{array}{c}0.584 \\
(0.518)\end{array}$ & & $\begin{array}{l}-1.117^{\star *} \\
(0.4904)\end{array}$ & $\begin{array}{l}0.568 \\
(0.320)\end{array}$ & $\begin{array}{c}0.898 \\
(0.381)\end{array}$ & $\begin{array}{c}0.557 \\
(0.314)\end{array}$ & $\begin{array}{c}0.895 \\
(0.378)\end{array}$ & & & $\begin{array}{c}0.734 \\
(0.689)\end{array}$ & $\begin{array}{c}0.438 \\
(0.348)\end{array}$ & $\begin{array}{c}0.753 \\
(0.408)\end{array}$ & $\begin{array}{c}1.015 \\
(0.462)\end{array}$ \\
\hline $\begin{array}{l}\text { often_without_ } \\
\text { cash }\end{array}$ & & & & & & & & & & & $\begin{array}{l}0.480^{\star \star \star} \\
(0.0855)\end{array}$ & $\begin{array}{l}0.672^{\star * \star} \\
(0.0958)\end{array}$ & & \\
\hline $\begin{array}{l}\text { corruption_ } \\
\text { police }\end{array}$ & & & & & & & & & & & $\begin{array}{l}1.488^{* * *} \\
(0.177)\end{array}$ & $\begin{array}{l}1.461^{* * *} \\
(0.166)\end{array}$ & & \\
\hline $\begin{array}{l}\text { corruption } \\
\text { judges }\end{array}$ & & & & & & & & & & & $\begin{array}{c}1.132 \\
(0.131)\end{array}$ & $\begin{array}{c}1.176 \\
(0.122)\end{array}$ & & \\
\hline $\begin{array}{l}\text { corruption_tax } \\
\text { officials }\end{array}$ & & & & & & & & & & & $\begin{array}{c}0.795^{\star} \\
(0.0974)\end{array}$ & $\begin{array}{c}0.849 \\
(0.0914)\end{array}$ & & \\
\hline $\begin{array}{l}\text { corruption } \\
\text { MP }\end{array}$ & & & & & & & & & & & $\begin{array}{c}0.974 \\
(0.135)\end{array}$ & $\begin{array}{l}0.928 \\
(0.119)\end{array}$ & & \\
\hline bribe_permit & & & & & & & & & & & $\begin{array}{c}1.247 \\
(0.177)\end{array}$ & $\begin{array}{c}1.495^{\star * \star} \\
(0.197)\end{array}$ & & \\
\hline bribe_police & & & & & & & & & & & $\begin{array}{l}0.757^{\star *} \\
(0.0976)\end{array}$ & $\begin{array}{l}0.723^{\star \star \star} \\
(0.0793)\end{array}$ & & \\
\hline
\end{tabular}




\begin{tabular}{|c|c|c|c|c|c|c|c|c|c|c|c|c|c|c|}
\hline Constant & $\begin{array}{l}0.00191^{\star \star \star} \\
(0.000351)\end{array}$ & $\begin{array}{r}1.644 \\
(2.031)\end{array}$ & $\begin{array}{l}-1.876^{* * *} \\
(0.0469)\end{array}$ & $\begin{array}{l}-0.382 \\
(0.760)\end{array}$ & $\begin{array}{c}0.00954^{\star \star *} \\
(0.00732)\end{array}$ & $\begin{array}{l}\underbrace{0.000235^{*}}_{* *} \\
(0.000184)\end{array}$ & $\begin{array}{l}0.00988^{\star * \star} \\
(0.00756)\end{array}$ & $\begin{array}{c}\underbrace{0.000238^{*}}_{* *} \\
(0.000187)\end{array}$ & $\begin{array}{l}0.00238^{* * *} \\
(0.000528)\end{array}$ & $\begin{array}{c}4.39 \mathrm{e}- \\
05^{\star * *} \\
(2.20 \mathrm{e}-05)\end{array}$ & $\begin{array}{c}0.00921^{\star \star \star} \\
(0.00804)\end{array}$ & $\begin{array}{r}0.000286^{\star * *} \\
(0.000259)\end{array}$ & \begin{tabular}{|c|}
0.00906 \\
$\star * *$ \\
$(0.0072$ \\
$7)$
\end{tabular} & $\begin{array}{c}0.000368 \\
* * * \\
(0.00029 \\
9)\end{array}$ \\
\hline Observations & 23,655 & 23,655 & 23,655 & 23,655 & 18,751 & 21,913 & 18,751 & 21,913 & 18,784 & 21,958 & 16,102 & 18,859 & 16,688 & 19,550 \\
\hline Base Controls & YES & YES & YES & YES & YES & YES & YES & YES & NO & NO & NO & NO & YES & YES \\
\hline $\begin{array}{l}\text { Country-Year } \\
\text { Dummies }\end{array}$ & YES & NO & YES & NO & YES & YES & YES & YES & YES & YES & YES & YES & YES & YES \\
\hline $\begin{array}{l}\text { Difference in } \\
\text { difference }\end{array}$ & $3.345^{\star * *}$ & & $0.341^{*}$ & & $4.266^{* \star *}$ & $1.640^{\star \star *}$ & $3.960^{\star \star \star}$ & $1.574^{* * *}$ & $4.134^{\star \star \star}$ & $1.427^{\star \star \star}$ & $3.692^{\star * \star}$ & $1.345^{\star * *}$ & $2.421^{* * *}$ & $0.787^{\star \star *}$ \\
\hline $\begin{array}{l}\text { Chi2 active- } \\
\text { inactive }=0\end{array}$ & 21.64 & & 3.79 & & 18.27 & 53.58 & 28.10 & 87.17 & 17.62 & 55.26 & 13.85 & 32.33 & 6.649 & 11.84 \\
\hline$p$ value & 0.0000 & & 0.0515 & & 0.0000 & 0.0000 & 0.0000 & 0.0000 & 0.0000 & 0.0000 & 0.0002 & 0.0000 & 0.0099 & 0.0006 \\
\hline
\end{tabular}

Robust se in parentheses, ${ }^{* * *} p<0.01,{ }^{* *} p<0.05,{ }^{*} p<0$. 
Appendix Table 5: Moran's I on Collapsed (by site) Residuals

Moran's I spatial correlogram EU

\begin{tabular}{|l|r|r|r|r|r|}
\hline \multicolumn{7}{|c|}{ (mean) resid } \\
\hline Distance bands & $\mathrm{I}$ & $\mathrm{E}(\mathrm{I})$ & $\mathrm{Sd}(\mathrm{I})$ & $\mathrm{z}$ & $\mathrm{p}$-value \\
\hline$(1-2]$ & 0.005 & -0.001 & 0.005 & 1.085 & 0.139 \\
$(1-3]$ & -0.008 & -0.001 & 0.003 & -2.302 & 0.011 \\
$(1-4]$ & -0.007 & -0.001 & 0.003 & -2.345 & 0.010 \\
\hline
\end{tabular}

${ }^{*} 1$-tail test

Moran's I spatial correlogram NON EU

\begin{tabular}{|l|r|r|r|r|r|}
\hline \multicolumn{7}{|c|}{ (mean) resid } \\
\hline Distance bands & $\mathrm{I}$ & $\mathrm{E}(\mathrm{I})$ & $\mathrm{Sd}(\mathrm{I})$ & $\mathrm{z}$ & $\mathrm{p}$-value \\
\hline$(1-2]$ & -0.052 & -0.001 & 0.006 & -9.314 & 0.000 \\
$(1-3]$ & -0.037 & -0.001 & 0.004 & -10.514 & 0.000 \\
$(1-4]$ & -0.030 & -0.001 & 0.003 & -10.475 & 0.000 \\
\hline
\end{tabular}

*1-tail test 


\section{GLOBUS Research Papers}

$4 / 2019$

Samuel Brazys, Arya Pillai and Johanne Døhlie Saltnes

EU Aid for Trade: Mitigating Global Trade Injustices?

$3 / 2019$

Johanne Døhlie Saltnes

Global Justice and Aid Effectiveness

Reforms of the European Union's

Development Policy

2/2019

Franziskus von Lucke

Principled Pragmatism in Climate

Policy?

The EU and Changing Practices of

Climate Justice

$1 / 2019$

Cathrine Holst

Global Gender Justice

Distributive Justice or Participatory

Parity?

$14 / 2018$

Kholiswa Malindini and Odile Mackett

Trade Liberalisation and Female

Employment in Botswana and South

Africa

$13 / 2018$

Arrigo Pallotti

The European Union and Africa

Depoliticised Development and the

Elusive Quest for Democracy and

Security

$12 / 2018$

Sonia Lucarelli

The EU and the Crisis of Liberal Order At Home and Abroad
$11 / 2018$

Graham Finlay

The European Union as a Tolerant

Actor

$10 / 2018$

Matthieu Burnay and Marta Hermez

Towards Global Justice with Chinese

Characteristics

9/2018

Katie Verlin Laatikainen and Martin

Palouš

Contested Ground

The Campaign to Enhance the Status of the European Union in the UN

General Assembly

$8 / 2018$

Hayley Walker

Mutual Recognition in Global

Negotiations

The Case of the 2015 Paris Climate

Summit

$7 / 2018$

Cathrine Holst

Promoting Global Justice when

Backlash Strikes

EU and UN Beijing +20

$6 / 2018$

Espen D.H. Olsen

Out but Still In

Norway's Approach to Migration and Asylum as a non-EU State

$5 / 2018$

Samuel Brazys and Krishna C.

Vadlamannati

Aid Curse with Chinese

Characteristics?

Chinese Development Flows and

Economic Reform 
4/2018

Michela Ceccorulli

On Protection and Justice

The Proposals for Reform of the

Common European Asylum System

$3 / 2018$

Ben Tonra

The (In)Justices of Peacekeeping

EUFOR Tchad/RCA

$2 / 2018$

Nikola Tomić and Ben Tonra

The Pursuit of Justice through EU

Security Strategies

Sisyphus Redux?

$1 / 2018$

Alexa Zellentin

Different Angles on Climate Justice Insights from Non-domination and Mutual Recognition

6/2017

Mai'a K. Davis Cross

Europe's Foreign Policy and the Nature of Secrecy

$5 / 2017$

Bettina Ahrens

The Solidarisation of International

Society

The EU in the Global Climate Change Regime
$4 / 2017$

Mai'a K. Davis Cross

EU Institutions and the Drive for Peace The Power of Ideas

$3 / 2017$

Kjartan Koch Mikalsen

Equal Sovereignty

On the Conditions of Global Political Justice

2/2017

Helene Sjursen

Global Justice and Foreign Policy

The Case of the European Union

1/2017

Franziskus von Lucke

O Justice, Where Art Thou?

Developing a New Take on Climate

Justice

$1 / 2016$

Erik O. Eriksen

Three Conceptions of Global Political Justice 


\section{GLOBUS Research Papers}

The GLOBUS Research Papers are pre-print manuscripts on the EU's contribution to global justice as well as the wider question of Global Political Justice. The series is multidisciplinary, with a particular emphasis on the fields of international relations, political science, political theory, sociology and law.

\section{Reconsidering European Contributions to Global Justice - GLOBUS}

GLOBUS is a research project that critically examines the European Union's contribution to global justice. Challenges to global justice are multifaceted and what is just is contested. Combining normative and empirical research GLOBUS explores underlying political and structural obstacles to justice. Analyses of the EU's positions and policies are combined with in-depth studies of non-European perspectives on the practices of the EU. Particular attention is paid to the fields of migration, trade and development, cooperation and conflict, as well as climate change. GLOBUS' team of researchers covers the disciplines of politics, international relations, law, economics, sociology and political theory. The project is coordinated by ARENA Centre for European Studies at the University of Oslo and has partners in Brazil, China, Germany, India, Ireland, Italy and South Africa. It is funded by the Horizon 2020 Programme of the European Union for the period 1.6.2016 - 31.5.2020.

\section{Series Editor}

Helene Sjursen, ARENA Centre for European Studies, University of Oslo GLOBUS Coordinator

\section{Editorial Board}

Thomas Diez

Erik O. Eriksen

Sonia Lucarelli Pundy Pillay

Ben Tonra
Institute of Political Science, University of Tübingen ARENA Centre for European Studies, University of Oslo Department of Political and Social Sciences, University of Bologna Wits School of Governance, University of Witwatersrand School of Politics and International Relations, University College Dublin 